\title{
Multiple sclerosis in a child with neurofibromatosis type I-clinical management of a challenging case
}

\author{
Kamil Kośmider ${ }^{1, A-D, F \oplus}{ }^{\oplus}$, Agata Kozakiewicz ${ }^{1, B, D, F}{ }^{,}$, Aleksandra Filipiuk ${ }^{1, B, D, F}$, \\ Dorota Sławińska ${ }^{2, B-C, F \oplus, ~ M o n i k a ~ L e j m a n ~}{ }^{3, A, E-F} \oplus$, Joanna Zawitkowska ${ }^{2, A, E-F} \oplus$ \\ ${ }^{1}$ Student Scientific Society, Department of Paediatric Haematology, Oncology and Transplantology, Medical University, \\ Lublin, Poland \\ ${ }^{2}$ Department of Paediatric Haematology, Oncology and Transplantology, Medical University, Lublin, Poland \\ ${ }^{3}$ Laboratory of Genetic Diagnostics, Department of Paediatric Haematology, Oncology and Transplantology, Medical \\ University, Lublin, Poland \\ A - Research concept and design, B - Collection and/or assembly of data, C - Data analysis and interpretation, \\ $D$ - Writing the article, E-Critical revision of the article, F-Final approval of the article
}

Kośmider K, Kozakiewicz A, Filipiuk A, Sławińska D, Lejman M, Zawitkowska J. Multiple sclerosis in a child with neurofibromatosis type I clinical management of a challenging case. Ann Agric Environ Med. 2022; 29(2): 309-315. doi: 10.26444/aaem/142267

\begin{abstract}
A 13-year-old girl with neurofibromastosis (NF1) was admitted to the Department of Paediatric Haematology, Oncology and Transplantology due to progressive vision loss in September 2018. The patient was diagnosed with optic nerve gliomas and chemotherapy was initiated. During the treatment, the girl experienced muscle weakness in the lower limbs, and uncharacteristic lesions were detected in the spinal cord. Eventually, the girl was diagnosed with MS. The described case is one of the few reports of a child with coexisting NF1 and MS. The coincidence of these diseases is unusual and requires a multidisciplinary approach. Vision impairment in patients suffering from NF1 is typically associated with optic nerve gliomas, although it can be caused by other factors, such as MS, which is proven to have a higher prevalence in the NF1 population. Extensive ophthalmological diagnostics may not be conclusive, thus there is a need for the thorough neurological evaluation of patients with NF1 and visual deficits.
\end{abstract}

\section{Key words}

case report, central nervous system, demyelination, neurofibromatosis type 1, multiple sclerosis

\section{INTRODUCTION}

Neurofibromatosis type 1 (NF1, von Recklinghausen disease) is an autosomal dominant disorder characterized by the presence of numerous benign tumours of the nervous system [1]. The term 'neurofibroma' was introduced in 1881 by Friedrich Daniel von Recklinghausen, and initially there was only one condition known as neurofibromatosis [2]. However, at the end of the twentieth century different forms of the disease were identified (neurofibromatosis type 2, schwannomatosis) [3].

NF1 is a consequence of a genetic alteration in the NF1 gene (locus 17q11.2) and specific mutations can be identified in over $95 \%$ of patients, Although genetic testing is not obligatory in the diagnostics, it can be helpful in case of ambiguous clinical presentation of the disease [4]. A wide spectrum of NF1 anomalies have been found, including splice site mutations (28\%), reading-frame shift (24\%), nonsense mutations (21\%), missense and/or 1 to 8 amino acid deletions/ duplications (19\%), whole gene deletions (4\%), intragenic exon deletions/duplications (3\%), and others $(<1 \%)$, such as balanced translocations, all leading to dysfunction of neurofibromin, a tumour suppressor and a product of the NF1 gene [4]. The lack of neurofibromin's s protective function

Adress for correspondence: Kamil Kośmider, Student Scientific Society, Department of Paediatric Haematology, Oncology and Transplantology, Medical University, Lublin, Poland

E-mail: kamilkosmider96@gmail.com

Received: 21.05.2021; accepted: 14.09.2021; first published: 30.09.2021 leads to increased risk of benign and malignant tumours, especially in the nervous system [5]. The newest data obtained in Finland shows that NF1 is much more common than previously estimated, with a birth incidence of about $1 / 2000$ and a general prevalence of $1 / 4000[6,7]$.

Diagnosis is based on criteria developed in 1988 by National Institutes of Health (NIH), at least 2 of them must be met in order to diagnose NF1 (Tab. 1) [8]. However, in May 2021, a new proposal was published for the NF1 diagnostic criteria (Tab. 2) [9], which were developed using the modified Delphi method with the participation of global NF experts, non-NF specialists, as well as patients, foundations and patient advocacy organisations. Especially noteworthy is the introduction of genetic testing in the NF1 diagnostics, which was not present in the NIH criteria. This innovation will allow clinicians to diagnose NF1 and treat potential

Table 1. NIH criteria for diagnosis of NF1 [8]

\begin{tabular}{l} 
1. At least 6 café-au-lait spots greater than $5 \mathrm{~mm}$ in diameter before puberty, or \\
over $15 \mathrm{~mm}$ in post-pubertal individuals. \\
\hline 2.Two or more neurofibromas of any type, or one plexiform neurofibroma. \\
\hline 3. Freckling in the axillary (Crowe sign) or inguinal regions. \\
\hline 4.Optic glioma. \\
5.Two or more Lish nodules. \\
6.A distinctive bone lesion with sphenoid dysplasia, or thinning of the long bone \\
cortex with or without pseudarthrosis. \\
7.A first-degree relative (parent, sibling, or offspring) who meets NIH criteria.
\end{tabular}


Table 2. Revised diagnostic criteria for NF1 [9]

A. The diagnostic criteria for NF1 are met in an individual who does not have a parent diagnosed with NF1, if 2 or more of the following are present:

- Six or more café-au-lait macules over $5 \mathrm{~mm}$ in prepubertal individuals, and over $15 \mathrm{~mm}$ in postpubertal individuals.

- Freckling in the axillary (Crowe sign) or inguinal region.

- Two or more neurofibromas of any type or one plexiform neurofibroma.

- Optic glioma.

- Two or more Lish nodules identified by slit lamp examination, or 2 or more choroidal abnormalities - defined as bright, patchy nodules imaged by optical coherence tomography/near-infrared reflectance imaging.

- A distinctive bone lesion, such as sphenoid dysplasia ${ }^{2}$, anterolateral bowing of the tibia, or pseudarthrosis of a long bone.

- A heterozygous pathogenic NF1 variant with a variant allele fraction of $50 \%$ in apparently normal tissue, such as white blood cells.

B. The child of a parent who meets the diagnostic criteria specified in A merits a diagnosis of NF1 if one or more of the criteria in A are present

${ }^{1}$ If only café-au-lait macules and freckling are present, the diagnosis is most likely NF1, but exceptionally the person might have another diagnosis such as Legius syndrome. At least one of the 2 pigmentary findings (café-au-lait macules or freckling) should be bilateral.

${ }^{2}$ Sphenoid wing dysplasia is not a separate criterion in the case of an ipsilateral orbital plexiform neurofibroma.

complications in more individuals. For instance, the authors of these criteria recommend that genetic testing should be performed in patients with segmental clinical findings, in families with at least 2 affected siblings and unaffected parents, and finally in children in which NF1 is diagnosed based only on pigmentary lesions. Moreover, DNA analysis in more NF1 patients will hopefully result in the detection of new pathological NF1 variants, especially those associated with atypical or severe course of the disease [9].

Optic pathway glioma (OPG) is the most common tumour occurring in children suffering from NF1, with an estimated prevalence of $15 \%-20 \%$, although up to $50 \%$ of cases might be asymptomatic $[10,11,12,13]$. OPGs associated with NF1 are mostly identified in younger children, as they can be found in $22 \%$ patients under 10 years of age, whereas in patients aged $10-19.9$ years, OPGs occur in $10-15 \%$ of cases [11]. Optic nerves are most often affected, whereas optic chiasm and the retrochiasmatic region of the optic pathway are less frequent locations of OPGs [11, 12]. Optic nerve gliomas (ONGs) are manifested by visual acuity (VA) and visual field (VF) defects, papilledoema, strabismus or relative afferent pupillary defects [13].

Multiple sclerosis (MS) is a chronic demyelinating disease of the central nervous system (CNS) with a ranging prevalence from 140/100,000 in North America and 108/ 100,000 in Europe to 2.1 and 2.2/100,000 in Sub-Saharan Africa and East Asia, respectively [14, 15]. The majority of cases are diagnosed in adult patients, with paediatric onset MS occurring in $1.7 \%-5.6 \%$ of all MS patient, with the majority of the children suffering from the relapsingremitting form of MS [15].

It has been proven that there is a relationship between NF1 and the higher incidence of certain neurological diseases, such as epilepsy, headache and sleep disorders [16]. This case report presents the details of a paediatric patient suffering from NF1 who was also diagnosed with MS. The diagnostic process and challenges in differential diagnosis are described, highlighting how the symptoms of MS can resemble clinical manifestations of NF1, which may delay diagnosis and negatively affect the patient's outcome. The current state of knowledge regarding the link between NF1 and MS and possible causes of that association are also reviewed.

\section{CASE REPORT}

A 13-year-old girl with NF1 was admitted to the Department of Paediatric Haematology, Oncology and Transplantology due to rapid deterioration in VA and VF in September 2018. The child had been previously diagnosed with epilepsy and treated with valproic acid. Both parents also suffered from NF1. Physical examination revealed features of NF1, such as Café-au-lait spots and axillary and inguinal freckling (Crowe's sign). The multi-disciplinary diagnostic process of the patient as well as the applied treatment and results of magnetic resonance imaging (MRI) are presented in Table 3. The girl was finally diagnosed with MS and is currently undergoing therapy with dimethyl fumarate, which has resulted in an improvement in her neurological condition.

\section{DISCUSSION}

The girl underwent a long diagnostic process carried out in various departments at different medical centres. There are several reasons for that, one of the most notable being the fact that diagnosing MS in paediatric population poses a significant challenge for physicians. Data obtained during a nationwide study conducted in Germany has proved, that MS in children is a very rare event, with estimated incidence of $0.65 / 100,000$ children [17]. One of the characteristic red flag symptoms of a demyelinating disease in patients below the age 18 of years is VA and VF impairment. Optic neuritis is proven to be an initial finding in $14 \%$ - 35\% of children suffering from MS [15].

Beginning in November 2017, the presented patient experienced deterioration of VA and VF. Initial diagnostics including MRI, ophthalmological consultation, as well as electroretinography and visual evoked potential test, did not indicate the cause of the progressive vision loss. However, re-examination performed in our Department in September 2018 revealed lesions characteristic of ONGs. Adequate therapy of ONGs using vinblastine (VBL) led to improvement in the patient's vision and reduction in optic nerves diameters, despite the premature discontinuation of the treatment. Further improvement was obtained after the initiation of MS treatment. This indicated that VA and VF impairment could have been the consequence of coexisting ONGs and optic neuritis in the course of the MS.

Visual evoked potential tests play an important role in paediatric MS diagnosis but, unfortunately, in the described case they failed to reveal demyelinating process occurring in the optic nerves; therefore, at that stage, MS was not considered as a possible cause [15]. Moreover, deterioration of the girl's neurological condition could have been a consequence of VBL chemotherapy, as well as intramedullary astrocytomas. VBL is known to cause mild neuropathy; however, a case of severe neurotoxicity leading to disability in a 20 -year-old female patient was also reported [18]. It was decided to reduce the dose, and eventually discontinue treatment, but deterioration of the patient's condition led to further diagnostics. Additional tests were performed, including MRI of the spinal cord in March 2019 (Fig. 1-2) and a cerebrospinal fluid (CSF) examination in September 2019. Uncharacteristic lesions in the spinal cord described at the time as possible intramedullary astrocytomas were misleading, especially considering that the diagnosis of 
Table 3. Diagnostics and treatment of the patient

\begin{tabular}{|c|c|c|c|c|c|c|}
\hline Period & Department & Clinical background & $\begin{array}{l}\text { Diagnostic tests results including } \\
\text { magnetic resonance imaging (MRI) }\end{array}$ & Current diagnosis & Applied treatment & $\begin{array}{l}\text { Treatment } \\
\text { results }\end{array}$ \\
\hline $\begin{array}{l}\text { October } \\
2010\end{array}$ & $\begin{array}{l}\text { Department } \\
\text { of Paediatric } \\
\text { Otolaryngology }\end{array}$ & $\begin{array}{l}\text { The patent was admitted to hospital } \\
\text { in order to undergo tonsillectomy } \\
\text { and suffered a generalized tonic- } \\
\text { clonic seizure during induction of } \\
\text { anaesthesia. }\end{array}$ & $\begin{array}{l}\text { Electroencephalogram (EEG) } \\
\text { monitoring revealed generalised } \\
\text { paroxysmal abnormalities. } \\
\text { Computed tomography of the } \\
\text { cerebrum revealed no abnormality. }\end{array}$ & Epilepsy. & $\begin{array}{l}\text { Successful chronic } \\
\text { treatment with } \\
\text { valproic acid (VPA) } \\
\text { at the dose of } 200 \\
\text { milligrams (mg) per } \\
\text { os (p.o.) twice a day. }\end{array}$ & $\begin{array}{l}\text { No further } \\
\text { seizures were } \\
\text { reported } \\
\text { during VPA } \\
\text { treatment. }\end{array}$ \\
\hline
\end{tabular}

\begin{tabular}{|c|c|c|c|c|c|c|}
\hline $\begin{array}{l}\text { November } \\
2017\end{array}$ & $\begin{array}{l}\text { Department } \\
\text { of Paediatric } \\
\text { Neurology }\end{array}$ & $\begin{array}{l}\text { Severe headache and progressive } \\
\text { VA (visual acuity) and VF (visual } \\
\text { field) deterioration. Occurrence } \\
\text { of characteristic symptoms, such } \\
\text { as numerous Café-au-lait spots, } \\
\text { Crowe's sign, along with a positive } \\
\text { family history, led to the diagnosis } \\
\text { of neurofibromatosis type } 1 \\
\text { (NF1). The patient was referred } \\
\text { to the Department of General } \\
\text { Ophthalmology. }\end{array}$ & $\begin{array}{l}\text { MRI of cerebrum demonstrated } \\
\text { hamartomatous changes within } \\
\text { the deep brain structures and in } \\
\text { the mesencephalon, characteristic } \\
\text { for NF1. }\end{array}$ & $\begin{array}{l}\text { Neurofibromatisis } \\
\text { type I. }\end{array}$ & $\begin{array}{l}\text { Discontinuation } \\
\text { of VPA. }\end{array}$ & $\begin{array}{l}\text { Patients did } \\
\text { not suffer } \\
\text { from seizures } \\
\text { despite } \\
\text { discontinuation } \\
\text { of the anti- } \\
\text { epileptic } \\
\text { treatment. }\end{array}$ \\
\hline $\begin{array}{l}\text { November } \\
2017\end{array}$ & $\begin{array}{l}\text { Department } \\
\text { of General } \\
\text { Ophthalmology }\end{array}$ & $\begin{array}{l}\text { Thepatient was diagnosed with optic } \\
\text { neuropathy of unknown etiology. }\end{array}$ & $\begin{array}{l}\text { On the basis of molecular genetic } \\
\text { testing, Leber's hereditary optic } \\
\text { neuropathy was excluded. }\end{array}$ & $\begin{array}{l}\text { Neurofibromatisis } \\
\text { type I. } \\
\text { Optic neuropathy } \\
\text { of unknown } \\
\text { etiology. }\end{array}$ & $\begin{array}{l}\text { Intravenous (i.v.) } \\
\text { methylprednisolone } \\
(2 \times 250 \mathrm{mg}) .\end{array}$ & $\begin{array}{l}\text { Temporary } \\
\text { improvement } \\
\text { in VA and VF } \\
\text { was achieved. }\end{array}$ \\
\hline
\end{tabular}

\begin{tabular}{|c|c|c|c|c|c|c|}
\hline March 2018 & $\begin{array}{l}\text { Department } \\
\text { of General } \\
\text { Ophthalmology }\end{array}$ & $\begin{array}{l}\text { The patient underwent } \\
\text { electroretinography and visual } \\
\text { evoked potential test which } \\
\text { supported the diagnosis of optic } \\
\text { neuropaty, but did not allow } \\
\text { determination of the exact cause of } \\
\text { the condition. }\end{array}$ & $\begin{array}{l}\text { Visual evoked potential test revealed } \\
\text { prolongation of P100 latency and } \\
\text { reduced aplitudes in both eyes. }\end{array}$ & $\begin{array}{l}\text { Neurofibromatisis } \\
\text { type I. } \\
\text { Optic neuropathy } \\
\text { of unknown } \\
\text { etiology. }\end{array}$ & & \\
\hline $\begin{array}{l}\text { September } \\
2018\end{array}$ & $\begin{array}{l}\text { Department } \\
\text { of Paediatric } \\
\text { Haematology, } \\
\text { Oncology and } \\
\text { Transplantology }\end{array}$ & $\begin{array}{l}\text { On the basis of imaging } \\
\text { examinations and neurosurgical } \\
\text { consultation, as well as the patient's } \\
\text { rapidly deteriorating condition and } \\
\text { coexisting NF1, optic gliomas were } \\
\text { diagnosed and chemotherapy was } \\
\text { initiated. After a month there was a } \\
\text { worsening in the patient's general } \\
\text { condition and the girl began to } \\
\text { suffer from abdominal pain, loss of } \\
\text { appetite and weight loss, pain and } \\
\text { muscle weakness in the lower limbs, } \\
\text { leading to movement impairment; } \\
\text { hence, the dose of vinblastine (VBL) } \\
\text { was reduced by 50\%. Despite the } \\
\text { reduction in the dose of VBL, there } \\
\text { was a further deterioration in the } \\
\text { neurological condition, causing } \\
\text { immobilization of the patient. }\end{array}$ & $\begin{array}{l}\text { MRI scans of the cerebrum showed } \\
\text { dilatation of the optic nerves (left } \\
6 \mathrm{~mm} \text {, right } 5 \mathrm{~mm} \text { ), indicating optic } \\
\text { nerve gliomas. Observed lesions } \\
\text { were not contrast-enhancing, as } \\
\text { proven after administration of } \\
\text { gadolinium-based contrast. }\end{array}$ & $\begin{array}{l}\text { Neurofibromatosis } \\
\text { type I. } \\
\text { Optic gliomas. }\end{array}$ & $\begin{array}{l}\text { VBL i.v. at the dose } \\
\text { of } 9 \text { mg instead of } \\
\text { the most common } \\
\text { first-line treatment } \\
\text { for low grade } \\
\text { glioma, consisting } \\
\text { of vincristine and } \\
\text { carboplatin, due } \\
\text { to lower toxicity of } \\
\text { VBL compared to } \\
\text { standard first-line } \\
\text { drugs. } \\
\text { The dose was } \\
\text { reduced to } 4.5 \text { mg } \\
\text { i.v. after a month } \\
\text { of therapy due } \\
\text { to deterioration } \\
\text { of the patient's } \\
\text { neurological } \\
\text { condition. }\end{array}$ & $\begin{array}{l}\text { There was a } \\
\text { significant } \\
\text { improvement } \\
\text { in VA and VF, } \\
\text { and no further } \\
\text { deterioration } \\
\text { of vision } \\
\text { occured. }\end{array}$ \\
\hline March 2019 & $\begin{array}{l}\text { Department } \\
\text { of Paediatric } \\
\text { Haematology, } \\
\text { Oncology and } \\
\text { Transplantology }\end{array}$ & $\begin{array}{l}\text { The patient's neurological condition } \\
\text { worsened; chemotherapy was } \\
\text { therefore discontinued. MRI was } \\
\text { performed and hospitalization in } \\
\text { the Department of Child Neurology } \\
\text { planned. }\end{array}$ & $\begin{array}{l}\text { Previously diagnosed dilatation } \\
\text { of the optic nerves and their } \\
\text { asymmetry were not found in the } \\
\text { MRI scans of the cerebrum. } \\
\text { MRI of the spinal cord revealed } \\
\text { poorly demarked high-intensity } \\
\text { focal lesions in the spinal cord on } \\
\text { T2-weighted images, one at the C2/ } \\
\text { C3 level ( } 27 \times 8 \mathrm{~mm}) \text {, the other at the } \\
\text { C4/C5 level ( } 29 \times 6 \mathrm{~mm}) \text {. Moreover, } \\
\text { minor foci were also found in the } \\
\text { thoracic and lumbar sections of } \\
\text { the spinal cord. It was concluded } \\
\text { that these lesions were most likely } \\
\text { intramedullary astrocytomas; } \\
\text { however, other pathologies were } \\
\text { not excluded. }\end{array}$ & $\begin{array}{l}\text { Neurofibromatosis } \\
\text { type I. } \\
\text { Optic gliomas. }\end{array}$ & $\begin{array}{l}\text { Discontinuation of } \\
\text { the chemotherapy } \\
\text { due to further } \\
\text { worsening in } \\
\text { the patient's } \\
\text { neurological } \\
\text { condition. }\end{array}$ & $\begin{array}{l}\text { Stabilization in } \\
\text { VA and VF was } \\
\text { achieved. }\end{array}$ \\
\hline
\end{tabular}


Table 3. Diagnostics and treatment of the patient (continuation)

\begin{tabular}{|c|c|c|c|c|c|c|}
\hline Period & Department & Clinical background & $\begin{array}{l}\text { Diagnostic tests results including } \\
\text { magnetic resonance imaging (MRI) }\end{array}$ & Current diagnosis & Applied treatment & $\begin{array}{l}\text { Treatment } \\
\text { results }\end{array}$ \\
\hline July 2019 & $\begin{array}{l}\text { Department of } \\
\text { Child Neurology }\end{array}$ & $\begin{array}{l}\text { During the neurological } \\
\text { examination, bilateral pyramidal } \\
\text { symptoms (Babinski reflex, } \\
\text { Chaddock reflex) were revealed. }\end{array}$ & $\begin{array}{l}\text { Results of MRI were similar to those } \\
\text { of the study performed in March } \\
2019 .\end{array}$ & $\begin{array}{l}\text { Neurofibromatosis } \\
\text { type I. } \\
\text { Optic gliomas. }\end{array}$ & & \\
\hline $\begin{array}{l}\text { September } \\
\text { - October } \\
2019\end{array}$ & $\begin{array}{l}\text { Department } \\
\text { of Paediatric } \\
\text { Haematology, } \\
\text { Oncology and } \\
\text { Transplantology }\end{array}$ & $\begin{array}{l}\text { Further neurological worsening } \\
\text { occurred, the patient suffered from } \\
\text { urinary hesitancy and paraesthesia } \\
\text { of the upper and lower limbs. }\end{array}$ & $\begin{array}{l}\text { Serologic tests (ELISA and } \\
\text { Western Blot) for Lyme disease } \\
\text { were performed but no IgG and } \\
\text { IgM antibodies against Borrelia } \\
\text { burgdorferi were detected. A lumbar } \\
\text { puncture was performed and the } \\
\text { cerebrospinal fluid (CSF) examined. } \\
\text { There were no Borrelia burgdorferi- } \\
\text { specific antibiodies in the CSF, nor } \\
\text { were antibodies to aquaporin-4 } \\
\text { found in serum. Therefore, } \\
\text { neuroborreliosis and neuromyelitis } \\
\text { optica (Devic's disease) were } \\
\text { excluded. There were, however, } \\
\text { oligoclonal IgG bands in the CSF. }\end{array}$ & $\begin{array}{l}\text { Neurofibromatosis } \\
\text { type I. } \\
\text { Optic gliomas. }\end{array}$ & & \\
\hline
\end{tabular}

\begin{tabular}{|c|c|c|c|c|c|c|}
\hline $\begin{array}{l}\text { October } \\
2019\end{array}$ & $\begin{array}{l}\text { Department } \\
\text { of Paediatric } \\
\text { Haematology, } \\
\text { Oncology and } \\
\text { Transplantology }\end{array}$ & $\begin{array}{l}\text { Multi-disciplinary council with } \\
\text { the participation of a neurologist, } \\
\text { radiologist and physicians from } \\
\text { our department took place, during } \\
\text { which, taking into consideration } \\
\text { changes in the latest MRI scans, } \\
\text { oligoclonal bands in the CSF } \\
\text { and the course of the disease, it } \\
\text { was concluded that the patient's } \\
\text { symptoms were of strictly } \\
\text { neurological origin. Therefore, it was } \\
\text { decided to continue diagnostics at } \\
\text { the Department of Neurology and } \\
\text { Epileptology. }\end{array}$ & $\begin{array}{l}\text { MRI scans revealed that new } \\
\text { well-delimited hyperintense } \\
\text { lesions had appeared in the spinal } \\
\text { cord. Moreover, the old lesions } \\
\text { were better demarked than } \\
\text { before. Relatively fast progress } \\
\text { of radiological changes gave rise } \\
\text { to the suspicion of an ongoing } \\
\text { demyelinating process in the central } \\
\text { nervous system. }\end{array}$ & $\begin{array}{l}\text { Neurofibromatosis } \\
\text { type I. } \\
\text { Optic gliomas. } \\
\text { Unspecified } \\
\text { demyelinating } \\
\text { disease of the } \\
\text { central nervous } \\
\text { system. }\end{array}$ & & \\
\hline $\begin{array}{l}\text { November } \\
2019\end{array}$ & $\begin{array}{l}\text { Department of } \\
\text { Neurology and } \\
\text { Epileptology }\end{array}$ & $\begin{array}{l}\text { The patient suffered from gait } \\
\text { disturbances and difficulties in } \\
\text { initiating micturition. Bilateral } \\
\text { pyramidal signs were present } \\
\text { (Babinski and Chaddock reflexes), } \\
\text { Romberg test was positive. } \\
\text { Deviation of the tongue to the right } \\
\text { was also found. There was severe } \\
\text { weakness and hyperreflexia in the } \\
\text { lower extremities. Based on the MRI } \\
\text { results, presence of the oligoclonal } \\
\text { bands in the CSF and the clinical } \\
\text { presentation the patient was } \\
\text { diagnosed with multiple sclerosis } \\
\text { and proper therapy was initiated. }\end{array}$ & & $\begin{array}{l}\text { Neurofibromatosis } \\
\text { type I. } \\
\text { Optic gliomas. } \\
\text { Multiple sclerosis. }\end{array}$ & $\begin{array}{l}\text { Methylprednisolone } \\
(500 \text { mg i.v.) for } \\
5 \text { days. Chronic } \\
\text { treatment with } \\
\text { dimethyl fumarate } \\
\text { was initiated ( } 2 \times 240 \\
\text { mg p.o. per day). }\end{array}$ & $\begin{array}{l}\text { After applied } \\
\text { treatment, } \\
\text { the patient's } \\
\text { neurological } \\
\text { condition } \\
\text { improved, } \\
\text { especially } \\
\text { in gait and } \\
\text { micturition. }\end{array}$ \\
\hline April 2020 & $\begin{array}{l}\text { Department of } \\
\text { Neurology and } \\
\text { Epileptology }\end{array}$ & $\begin{array}{l}\text { Neurological examination revealed } \\
\text { deviation of the tongue to the } \\
\text { right, positive bilateral Babinski } \\
\text { sign, hyperreflexia in the lower } \\
\text { extremities, positive Romberg } \\
\text { test. The patient was able to move } \\
\text { independently, there were no } \\
\text { micturition disorders, VA and VF } \\
\text { were partially recovered. }\end{array}$ & $\begin{array}{l}\text { Results of MRI were similar to those } \\
\text { of the study performed in October } \\
2019 .\end{array}$ & $\begin{array}{l}\text { Neurofibromatosis } \\
\text { type I. } \\
\text { Optic gliomas. } \\
\text { Multiple sclerosis. }\end{array}$ & $\begin{array}{l}\text { Treatment with } \\
\text { dimethyl fumarate } \\
\text { ( } 2 \times 240 \text { mg p.o. per } \\
\text { day) was sustained. }\end{array}$ & $\begin{array}{l}\text { The patient's } \\
\text { neurological } \\
\text { condition was } \\
\text { stabilized; } \\
\text { therefore, } \\
\text { the patent } \\
\text { was treated } \\
\text { with dimethyl } \\
\text { fumarate ever } \\
\text { since. }\end{array}$ \\
\hline
\end{tabular}

MS is largely based on an MRI examination [15]. However, detection of oligoclonal IgG bands in CSF was suggestive for the acquired demyelinating syndrome (ADS), as oligoclonal IgG bands are detected in $68 \%$ of ADSs cases in children from 12-17 years of age [19]. This group of diseases include paediatric MS, acute disseminated encephalomyelitis (ADEM), neuromyelitis optica spectrum disease (NMOSD) and clinically isolated syndrome (CIS). Oligoclonal IgG bands are proven to be highly predictive of ADSs in this age group (positive predictive value: 0.89 ; 95\% CI: 0.82-0.94; P $<0.0001$ ) [19]. NMOSD was considered as a possible cause of neurological symptoms, given the fact that the patient suffered from bilateral vision impairment, combined with manifestations of CNS damage and pathological changes in the spinal cord. However, IgG antibodies to aquaporin-4 (AQP4-IgG) in serum were not found. AQP4-IgG are highly specific for NMOSD, although according to international consensus, in the diagnostic criteria for NMOSD which 


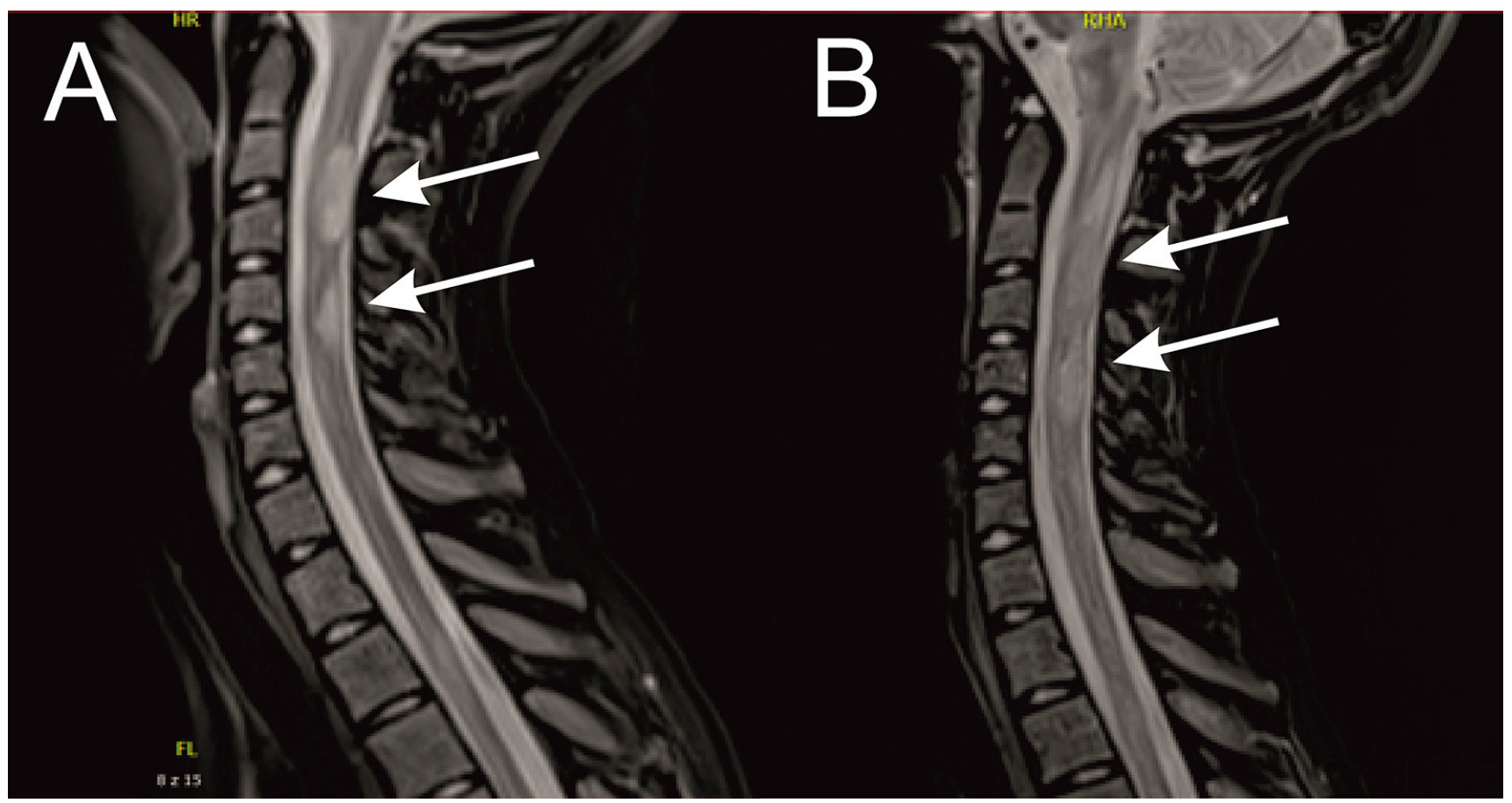

Figure 1. Cervical spine MRI

are applicable in paediatric patients, there is a possibility to diagnose NMOSD without detection of these antibodies [20]. Nevertheless, red flag symptoms which signal the possibility of an alternative to NMOSD diagnoses were observed. Most noticeably, the girl suffered from neurological deterioration that progressed over the months (e.g. progressive worsening occurred between October 2018 - March 2019). Such a course of the disease is rarely seen in patients suffering from NMOSD $(1 \%-2 \%)$ and is rather associated with MS. In NMOSD neurological worsening occurs during attacks.
Furthermore, MRI findings were also more suggestive of MS, as lesions in the spinal cord (Fig. 1-2) do not exceed 3 adjacent segments, whereas in NMOSD longitudinally extensive transverse myelitis (LETM) in the spinal cord involving at least 3 contiguous segments is characteristic [20]. NMOSD was therefore rejected as a cause of the deteriorating neurological condition. Another disease excluded during differential diagnostics was Lyme disease as no IgG and IgM antibodies against Borrelia burgdorferi in CSF were found.

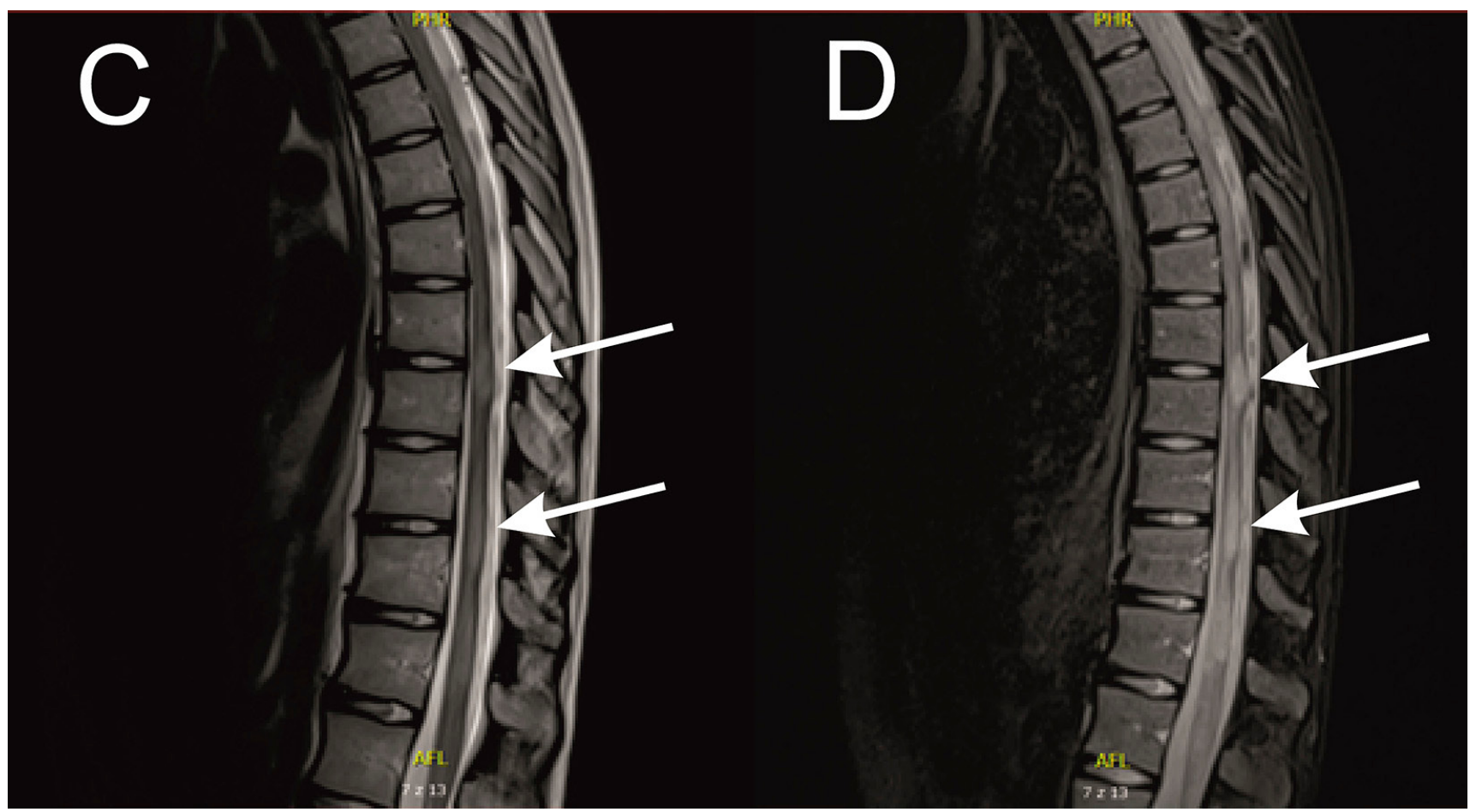

Figure 2. Thoracic spine MRI 
In the described patient, during the course of the disease, clinical CNS events which resulted in deterioration of the patient's neurological condition were observed. In October 2019 , the patient's symptoms were reassessed during a multidisciplinary council and it was concluded that VA and VF deterioration, previously viewed only as a manifestation of ONG, was in fact a consequence of bilateral gliomas as well as the first manifestation of ADS. In October 2018, relapse was observed when the girl experienced severe muscle weakness in the lower limbs which eventually led to immobilization. In September and October 2019, the patient experienced another relapse which caused urinary retention as well as paraesthesia of the upper and lower limbs. This worsening was combined with radiological progression, as in October 2019 new T2 hyperintense lesions had appeared in the spinal cord. According to the International Pediatric Multiple Sclerosis Study Group criteria for paediatric MS, at least two nonecephalophatic (not associated with consciousness or behavioural disturbances unexplained by fever or systemic illness) clinical CNS events separated by no less than 30 days and involving 2 separate CNS regions are sufficient to identify this disease. The girl was therefore diagnosed with MS and proper treatment was initiated [21].

Both NF1 and paediatric MS are rare diseases; therefore the question arises whether there is an association between a mutation in the NF1 gene and increased risk of developing MS. So far, only 2 cases of children with coexisting NF1 and MS have been reported; however, in both cases, neither a detailed clinical picture nor the differential diagnosis were presented [22].

An analysis of the private insurers' database conducted in the USA between 2006-2010 showed that among 8,579 NF1 patients, $25(0.3 \%)$ suffered from MS. This is a greater proportion compared to the non-NF1 population, in which of the 85,615 people, only $108(0.1 \%)$ had MS. However, the study had limitations: the obtained data was based on the International Classification of Diseases (ICD) codes used for insurance claims, and not on full medical records. As the authors of the study emphasize, coding errors could undermine the results of the entire study [16]. It is also worth noting that the seizure the girl experienced at the age of 5 could be related to NF1. It was proven that patients suffering from NF1 are much more likely to also have epilepsy [16].

Another interesting study was conducted at the French National Referral Centre for Neurofibromatosis in Paris, where an analysis of 1,507 adult patients with NF1 showed that patients with the NF1 mutation had more than twice the prevalence of MS (3.3/1,000), compared to the general French population (1.5/1000). Unfortunately, the small sample size and the fact that the study was carried out in a specialized medical centre in which patients with comorbidities of NF1 were more likely to seek help, were serious downsides of that study [23]. Therefore, the link between NF1 and MS remains uncertain.

There are 3 main hypotheses to explain the greater incidence of MS among patients suffering from NF1 [24]. The first is related to the embedding of the oligodendrocytemyelin glycoprotein (OMG) gene within the intron $27 \mathrm{~b}$ of the NF1 gene [24]. OMG takes part in the myelination of nerves in the CNS and it was believed that its malfunction might cause MS. This hypothesis was called into question by a study in which $O M G$ genes in 4 patients with coexisting NF1 and MS were analysed. Genetic alterations were discovered in 2 patients, whereas in the other 2 , no pathologies were revealed. It was concluded that a mutation in the $O M G$ gene is not sufficient for a person to develop MS [25].

The second hypothesis is based on the fact that NF1 is expressed in oligodendrocytes, which are the target of autoimmunological reaction in the course of MS. Mutations in the NF1 gene in zebrafish and mice are associated with increased oligodendrocyte precursor cells [24]. Moreover, NF1 dysfunction in genetically-engineered mouse models lead to impairment of nitric oxide-mediated blood-brain barrier function. These factors could promote an autoimmunological reaction in the CNS [24].

The third explanation concerns the abnormal Schwann cell proliferation caused by a loss of NF1 function [24]. Increased exposure to antigens expressed in peripheral myelin may activate auto-aggression towards them. Given that some of the Schwann cell antigens are shared with antigens in oligodendrocytes, it is possible that a cross-reaction is responsible for auto-immune demyelination in the CNS. The possible over-reactivity of the immune system in the course of NF1 could also be of importance [24].

\section{CONCLUSIONS}

The coincidence of NF1 and MS is a very rare phenomenon which requires thorough diagnostics. Effective cooperation between various medical specialists, as well as the correct interpretation of additional tests, are essential for the accurate diagnosis. Each case of NF1 should not be belittled, and the occurrence of other conditions with symptoms similar to those of NF1 must always be considered.

It should be emphasized that, as in the described case, symptoms associated with potential NF1 complications and early signs of MS may give a similar clinical picture, thus delaying diagnosis of the latter. The first symptoms of MS in children are often associated with optic neuritis; therefore, ONGs-elated vision loss may cause omission of the first signs of MS. Given the relatively high prevalence of ONGs among patients with NF1, early diagnosis of MS and other causes of optic neuritis in such patients is difficult, thus additional tests should always be performed in any case of diagnostic uncertainty. However, even extensive differential tests, including ophthalmological consultation, imaging tests, electroretinography, and visual evoked potential tests, may not be conclusive; therefore, the careful neurological evaluation of patients with NF1 and visual deficit are necessary. This is particularly important as early recognition and treatment of MS in children can potentially result in significantly better outcomes.

The presented case report should be considered as an example of a multidisciplinary diagnostic approach towards NF1 patients with comorbidities, especially in patients with coexisting demyelinating syndromes. Managing such cases poses difficulties for clinicians because hitherto no guidelines have been developed. Case reports such as that presented are crucial for raising clinical awareness, and may contribute to the development of appropriate diagnostic criteria and treatment strategies in patients with NF1 and demyelinating diseases. 


\section{REFERENCES}

1. Ly K, Blakeley J. The Diagnosis and Management of Neurofibromatosis Type 1. Med Clin North Am. 2019; 103(6): 1035-1054. https://doi. org/10.1016/j.mcna.2019.07.004

2. Crump T. Translation of case reports in Ueber die multiplen Fibrome der Haut und ihre Beziehung zu den multiplen Neuromen by F. v. Recklinghausen. Adv Neurol. 1981; 29: 259-275.

3. Antônio JR, Goloni-Bertollo EM, Trídico LA. Neurofibromatosis: chronological history and current issues. An Bras Dermatol. 2013; 88(3): 329-343. https://doi:10.1590/abd1806-4841.20132125

4. Messiaen LM. Molecular Diagnosis for NF1. In: Tadini G, Legius E, Brems H, editors. Multidisciplinary Approach to Neurofibromatosis Type 1. Cham: Springer International Publishing; 2020. p. 15-34.

5. Bergoug M, Doudeau M, Godin F, et al. Neurofibromin Structure, Functions and Regulation. Cells. 2020; 9(11): 2365. https://doi. org/10.3390/cells9112365

6. Kallionpää RA, Uusitalo E, Leppävirta J, et al. Prevalence of neurofibromatosis type 1 in the Finnish population. Genet Med. 2018; 20(9): 1082-1086. https://doi.org/10.1038/gim.2017.215

7. Uusitalo E, Leppävirta J, Koffert A, et al. Incidence and mortality of neurofibromatosis: a total population study in Finland. J Inves Dermatol. 2015; 135(3): 904-906. https://doi.org/10.1038/jid.2014.465

8. Neurofibromatosis: Conference Statement. Arch Neurol. 1988; 45(5): 575-578.

9. Legius E, Messiaen L, Wolkenstein P, et al. Revised diagnostic criteria for neurofibromatosis type 1 and Legius syndrome: an international consensus recommendation. Genet Med. 2021. https://doi.org/10.1038/ s41436-021-01170-5

10. Trevisson E, Cassina M, Opocher E, et al. Natural history of optic pathway gliomas in a cohort of unselected patients affected by Neurofibromatosis 1. J Neurooncol. 2017; 134(2): 279-287. https://doi. org/10.1007/s11060-017-2517-6

11. Sellmer L, Farschtschi S, Marangoni M, et al. Serial MRIs provide novel insight into natural history of optic pathway gliomas in patients with neurofibromatosis 1. Orphanet J Rare Dis. 2018; 13(1): 62. https://doi. org/10.1186/s13023-018-0811-9

12. Prada C, Hufnagel R, Hummel T, et al. The Use of Magnetic Resonance Imaging Screening for Optic Pathway Gliomas in Children with Neurofibromatosis Type 1. J Pediatr. 2015; 167(4): 851-856. https:// doi.org/10.1016/j.jpeds.2015.07.001
13. Campen CJ, Gutmann DH. Optic Pathway Gliomas in Neurofibromatosis Type 1. J Child Neurol. 2018; 33(1): 73-81. https://doi. org/10.1177/0883073817739509

14. Multiple Sclerosis International Federation. Atlas of MS 2013: mapping multiple sclerosis around the world. Mult Scler Int Fed http://www. msif.org/about-us/advocacy/atlas/ (access: 2021.05.14).

15. Alroughani R, Boyko A. Pediatric multiple sclerosis: a review. BMC Neurol. 2018; 18(1): 27. https://doi.org/doi: 10.1186/s12883-018-1026-3

16. Madubata CC, Olsen MA, Stwalley DL, et al. Neurofibromatosis type 1 and chronic neurological conditions in the United States: an administrative claims analysis. Genet Med. 2015; 17(1): 36-42. https:// doi.org/10.1038/gim.2014.70

17. Reinhardt K, Weiss S, Rosenbauer J, et al. Multiple sclerosis in children and adolescents: incidence and clinical picture - new insights from the nationwide German surveillance (2009-2011). Eur J Neurol. 2014; 21(4): 654-659. https://doi.org/10.1111/ene.12371

18. Suresh P, Kapoor R, Kapur BN. Severe neurotoxicity due to Vinblastine in Hodgkin lymphoma. South Asian J Cancer. 2014; 3(2): 147-148. https://doi.org/10.4103/2278-330X.130492

19. Boesen MS, Born AP, Jensen PEH, et al. Diagnostic Value of Oligoclonal Bands in Children: A Nationwide Population-Based Cohort Study. Pediatr Neurol. 2019; 97: 56-63. https://doi.org/10.1016/j. pediatrneurol.2019.03.002

20. Wingerchuk DM, Banwell B, Bennett JL, et al. International consensus diagnostic criteria for neuromyelitis optica spectrum disorders. Neurology. 2015; 85(2): 177-189. https://doi.org/10.1212/ WNL.0000000000001729

21. Krupp LB, Tardieu M, Amato MP, et al. International Pediatric Multiple Sclerosis Study Group criteria for pediatric multiple sclerosis and immune-mediated central nervous system demyelinating disorders: revisions to the 2007 definitions. Mult Scler. 2013; 19(10): 1261-1267. https://doi.org/10.1177/1352458513484547

22. Etemadifar M, Fatehi F, Sahraian MA, et al. Multiple sclerosis and neurofibromatosis type 1: report of seven patients from Iran. Mult Scler. 2009; 15(9): 1126-1130. https://doi.org/10.1177/1352458509106612

23. Bergqvist C, Hemery F, Ferkal S, et al. Neurofibromatosis I and multiple sclerosis. Orphanet J Rare Dis. 2020; 15(1): 186. https://doi.org/10.1186/ s13023-020-01463-z

24. Johnson MR, Ferner RE, Bobrow M, et al. Detailed analysis of the oligodendrocyte myelin glycoprotein gene in four patients with neurofibromatosis 1 and primary progressive multiple sclerosis. J Neurol Neurosurg Psychiatry. 2000; 68(5): 643-646. https://doi. org/10.1136/jnnp.68.5.643 